\author{
A.A. Urisbaeva (i) , S.R. Ermuhametova ${ }^{(D)}$ D.A. Alkebaeva \\ Al-Farabi Kazakh National University, Kazakhstan, Almaty, \\ e-mail: Urisbaevaainur_7@mail.ru; saulehan11r@mail.ru; alkebaeva.zhanat@gmail.com
}

\title{
CIVIL PROCEEDINGS AS A PROCEDURAL FORM OF THE JUDICIAL POWER REALIZATION
}

The problem of the ratio of legal categories to "civil law" and "civil process" is a debatable one in the civility procedural doctrine. For the purposes of this study, these legal categories are used as identical. The term "civil proceedings" is used in the current procedural legislation. In the light of the reform of the current procedural legislation, the definition of the concept, purpose and objectives of civil litigation is a relevant. The concept of civil procedure (process) in the doctrine of civil procedural law is debatable. The science of civil procedural law discusses the concepts of a broad and narrow understanding of the civil process. Proponents of narrow interpretation refer to the civil process only the work of the court to implement justice in civil cases.

As well as the scientific article states theoretical and practical research of civil proceedings as specialization as a procedural form. General provisions having initial importance for such cognition by the science of civil procedure law are defined and characterized, their influence on specialization and its characteristic is also recognized. According to the authors, this approach reflects the development of branch domestic legislation and law, legal practice and legal doctrine, with a special role - procedural. It allows to correctly establish and correctly explain, holistically and systematically understand the legal form of the procedural form and its action in accordance with the subject of the judicial examination, when the results achieved are verified, confirmed or denied its perfection.

Key words: civil procedure, civil proceedings, arbitration process, procedural form, the science of civil procedure law, specialization as a research area.

\author{
А.А. Урисбаева, С.Р. Ермухаметова, А.А. Алкебаева \\ Әл-Фараби атындағы Қазақ ұлттық университеті, Қазақстан, Алматы қ., \\ e-mail: Urisbaevaainur_7@mail.ru; saulehan11r@mail.ru; alkebaeva.zhanat@gmail.com
}

\section{Азаматтық сот ісін жүргізу - сот бимігін жүзеге асырудың іс жүргізу нысаны ретінде}

«Азаматтық сот ісін жүргізу» және «азаматтық процесс» құқықтық санаттарының арақатынасы проблемасы өркениеттік іс жүргізу доктринасында пікірталас болып табылады. Осы зерттеудің мақсаттары үшін осы құқықтық санаттар ұқсас ретінде қолданылады. Қолданыстағы іс жүргізу заңнамасында азаматтық сот ісін жүргізу термині пайдаланылады. Тұрғысынан реформалау қолданыстағы іс жүргізу заңнамасының түсінігі, мақсаттары мен міндеттері, азаматтық сот ісін жүргізу өзекті мәселелердің бірі болып табылады. Өркениеттік іс жүргізу құқығы доктринасында азаматтық сот ісін жүргізу (процесс) ұғымы пікірталас болып табылады. Азаматтық іс жүргізу құқығы ғылымында азаматтық процесті кең және тар түсінудің тұжырымдамалары талқыланады. Тар мағынада түсіндіруді жақтаушылар азаматтық, процеске тек соттың азаматтық істер бойынша сот төрелігін жүзеге асыру жөніндегі қызметін ғана жатқызаАы. Азаматтық процесс кең мағынаАа соттың және процестің басқа да қатысушыларының қызметін қамтилы.

Сонымен қатар, ғылыми мақалада азаматтық сот ісін жүргізудің теориялық-практикалық зерттеулері, оны іс жүргізу формасы ретінде мамандандыру көрсетіледі. Азаматтық іс жүргізу құқығын ғылымның осындай тануы үшін бастапқы маңызы бар жалпы ережелер айқындалады және сипатталады, сондай-ақ олардың мамандануына және оның сипаттамасына әсері де танылады. Авторлардың пікірінше, мұндай тәсіл салалық отандық заңнама мен құқықтың, заң тәжірибесі мен құқықтық, доктринаның, ерекше рөлді - іс жүргізу кезінде дамуын көрсетеАі. О^ іс жүргізу нысанының заңды ресімделуін және оның іс-әрекетін қол жеткізілген нәтижелермен тексерілгенде, оның жетілдірілуі расталғанда немесе теріске шығарғанда сот қарауының мәніне сәйкес дұрыс анықтауға және дұрыс түсіндіруге, тұтас және жүйелі түрде түсінуге мүмкіндік береді.

Түйін сөздер: азаматтық сот ісін жүргізу, азаматтық процесс, арбитраждық процесс, іс жүргізу нысаны, азаматтық іс жүргізу құқығы ғылымы, зерттеу бағыты ретінде мамандануы. 


\author{
А.А. Урисбаева, С.Р. Ермухаметова, А.А. Алкебаева \\ Казахский национальный университет им. аль-Фараби, Казахстан, г. Алматы, \\ e-mail: Urisbaevaainur_7@mail.ru; saulehan11r@mail.ru; alkebaeva.zhanat@gmail.com \\ Гражданское судопроизводство \\ как процессуамьная форма реализации судебной власти
}

\begin{abstract}
Проблема соотношения правовых категорий «гражданское судопроизводство» и «гражданский процесс» является дискуссионной в цивилистической процессуальной Аоктрине. А^я целей настоящего исследования данные правовые категории употребляются как тождественные. В действующем процессуальном законодательстве используется термин «гражданское судопроизводство». В свете реформирования действующего процессуального законодательства определение понятия, цели и задач гражданского судопроизводство является актуальным. Понятие гражАанского судопроизводства (процесса) в Аоктрине цивилистического процессуального права является Аискуссионным. В науке гражАанского процессуального права обсуждаются концепции широкого и узкого понимания гражданского процесса. Сторонники узкого толкования относят к гражАанскому процессу только Аеятельность суда по осуществлению правосудия по гражданским делам. В широком смысле гражАанский процесс вкАючает в себя Аеятельность суда и других участников процесса.

Также в научной статье констатируется теоретико-практическое исследования гражданского судопроизводства в качестве специализации его как процессуальной формы. Определяются и характеризуются общие положения, имеющие исходное значение Аля подобного познания наукой гражАанского процессуального права, также признается и их влияние на специализацию и ее характеристику. По мнению авторов, такой подхоА отражает развитие отраслевого отечественного законодательства и права, юридической практики и правовой доктрины, при особой роли - процессуальной. Он позволяет правильно установить и верно объяснить, целостно и системно понять юридическое оформление процессуальной формы и ее действие сообразно предмету судебного рассмотрения, когАа Аостигнутыми результатами проверяется, подтверждается или опровергается ее совершенство.

Кмючевые слова: гражданский процесс, гражданское судопроизводства, арбитражный процесс, процессуальная форма, наука гражданского процессуального права, специализация как направления исслеАования.
\end{abstract}

\section{Introduction}

The Constitutional Law on the Status of Courts and Judges in the Republic of Kazakhstan, adopted on 25 December 2000, has become a very important element in the formation and improvement of the judicial system. In particular, the status of courts and judges was determined by constitutional laws, the courts were united into a single system and were the optimal and effective basis for the construction of courts and trials.

The concept of civil justice is closely linked to the concept of civil justice, and the science of civil procedural law has been discussed throughout its history and development. Some authors provide a broader interpretation of the civil process and attempt to uncover the composition of its main components. Other points of view support the idea of a complex civil litigation process based on a thorough and comprehensive analysis of the relationship between procedural and procedural relations in civil proceedings.

There is a need to use objective protection of certain safeguards when the rights of individuals or organizations are violated by others and in the event of a future threat to remedies. He uses the right to defend himself against the obligatory side.

The right to protect the right is a category of material law. The Civil Code of the Republic of Kazakhstan provides for the protection of rights.

\section{Main Part}

The right to be protected is a procedural category. Law enforcement agencies legally define the form of enforcement as a definition of the right to protection and a decision to determine the practical situation of enforcement. The qualitative changes in the material legislation governing market relations show the need of society for procedural regulation. Public Relations: "The nature of the civil process - it creates various specific rights and therefore makes them inseparable." Consequently, the link between material and procedural standards has clearly visible methodological significance for both procedural law and the creation of a more effective form of civil dispute resolution (Baimoldina 2001:44). 
First, of all, we must understand the meaning of any stage of activity. The scene in the encyclopedic dictionary (from the Latin word "stadium") refers to the period and period of development of any thing that has its own qualitative features. A civil process is a system of certain actions that are systematically carried out, for example, by any activity. It combines actions at different levels into levels, periods, stages, and cycles. And in general, we are talking about its stages. However, in procedural law theory, the process was not resolved unilaterally. Because of different explanations, the word "withindoors" needs to be considered in more detail.

Many authors agree that the concept of "step by step" implies a series of procedural actions that are clearly aimed at one thing. Trials are conducted in stages. This is called the civil justice phases.

The proceedings are part of a trial that combines procedural actions aimed at achieving a specific goal. The stages of civil proceedings are closely related but are relatively separate parts of civil proceedings. They are separated from each other by a procedural decision made accordingly.

At the same time, there is no consensus on dividing the civil process into stages. A number of authors argue that civil proceedings are divided into the following stages:

- Proceedings in the court of first instance;

- Proceedings in the court of second instance;

- Judicial review of decisions, rulings and rulings;

- Review of judicial acts on newly discovered circumstances;

- Doing the deed (Rozhkova 2005:12).

Each stage is characterized by its own goals: either the resolution of the dispute (in the first stage), or the consideration of a complaint (protest) against the court's decision, which has not entered into legal force, and so on. But not every step is over. The trial may be terminated in the court of first instance if the court's decision has not been appealed or challenged.

However, if a decision or objection is given, the case is referred to the court of second instance (appeal and cassation). In this case, the proceedings may be initiated after the case is completed in the court of second instance. Only a small proportion of decisions and rulings that have come into force will be reviewed under supervision or under new circumstances. Thus, the trial can end at any stage. This sign is crucial in the distribution of civil proceedings by stages. Not all authors agree with the aforementioned division of the civil process. In theory, as a separate stage, the court of first instance conducts civil proceedings and prepares cases for consideration.

Russian prosecutor Y.K. Osipov reviewed seven lines.

Thus, M.Y. Lebedev defines civil proceedings as the statutory settled activities of the court and other participants in procedural legal relations concerning the consideration and resolution of disputes and other cases proceeding from the court material relations. In the opinion of N.A. Chechina and D.M. Chechot, civil proceedings are the procedure for the emergence and development of civil procedural relations, established for the right and rapid the court's handling and resolution of civil cases; the manner in how civil justice is done.

In order to give the most accurate definition of civil proceedings (process), it is necessary to list the most important features of it. The first sign is the civil procedural relations between the court and other participants in the trial, which are formed during the consideration and resolution of the case. These legal relations specify the rights and obligations of the subjects under civil procedural law. The second sign is that civil procedural relations have been legally settled. There is a relationship between civil procedural relations and procedural actions.

In conjunction with these signs, the following definition can be given: a civil process is a set of procedural proceedings and civil procedure, which is settled between the court and other participants in the civil procedure (Yurova 2008 a: 14-15).

According to Gurvich's argument, the process is thus divided: "First, its stages are revealed in procedural relations, and secondly, the unique basis of distribution is lost."

At the same time, the question arises as to why the cassation and supervision process is being investigated, as well as the stages of civil proceedings and preparation of the case for trial. Attempts are being made at all stages of the proceedings to initiate civil proceedings and prepare the case for trial. From this, it would be desirable to divide the proceedings into the court of first instance into three parts: initiation of a case, preparation for trial and consideration of the case. The following are:

1. Trials in the first instance (from the moment of initiation of a case, decision or decision).

2. Proceedings in the court of second instance (appeal or cassation or protest, review of rulings and decisions).

3. The procedure for reviewing court decisions and rulings in the supervisory order. 
4. Proceedings for review of court decisions, rulings and rulings on newly discovered circumstances.

5. Executive production (Vol.5 P.280).

Each stage of the proceedings has its responsibilities: for the court of first instance - the consideration of the dispute; for the court of second instance - appeal, cassation, protest against the decision or decision of the court of first instance; for the supervisory court - consideration of the protest of the official by the acts of the courts of first and second instance; executive proceedings - execution of court orders.

Initially, V.M. According to Sherstuk, civil proceedings consist of only two stages: trial and judicial review of the courts of first instance. Later, the author proposed to change this view and divide the civil process into cycles of law, not at the stage. These cycles include:

- Proceedings in the court of first instance;

- Proceedings in the court of second instance;

- Review of the case as a matter of supervision;

- Revisiting the case in new circumstances;

- Executive production.

Each of these cycles includes three factors: initiation of a case, preparation for trial and consideration of the case.

All of the above is a key element in the development of the civil process.

The stages of the civil process are a set of proceedings aimed at achieving the following objectives: the adoption of a lawsuit (complaint), trials, litigation, the publication of court acts, etc.

The civil process is determined by civil procedure law, as well as by the civil process (civil proceedings) established by civil procedure law. In our view, the stages of civil proceedings are stages that end with an act of court in accordance with the Civil Procedure Code. Therefore, agreeing with Osipov's opinion, the first stage of civil proceedings should begin from the moment of filing the complaint, from the moment of the decision on their conviction, acceptance or rejection. At this stage, judicial acts may be issued that could lead to the end of the civil process.

The correctness of the consideration and resolution of a civil case is inextricably linked to the notion of legality in civil proceedings, since procedural law in the implementation of justice is to be properly considered.

The legality is that strong legal foundation, without which it is impossible to build a house, because such a house will be destroyed, because at first cracks will appear in the walls, and then its complete destruction. So, in the judicial process: there will be no proper enforcement of the rule of law - there will not be properly ensured disposability, adversarial parties and much more, without which it is impossible to implement justice effectively and quickly restore violated the rights and legitimate interests of individuals and entities. It is worth bearing in note that in accordance with procedural law not all violations of the law entail the cancellation of a court order by a higher court.

The requirement of proper consideration and resolution of the case applies not only to the law enforcement actions of the court, but also to all other subjects of civil proceedings, whose conduct in the consideration and resolution of the case must correspond to their rights and responsibilities, as established by procedural law (Yurova 2008 b: 12-34).

The timeliness of the civil case means that the deadlines for the commission of proceedings are met. As the general objectives of civil proceedings, correctness and timeliness are interconnected, as deadlines are set by law. When it is clear, the provisions of art should be taken into account when it is clear. 6 Convention on the Protection of Human Rights and Fundamental Freedoms, which provides for the right to a fair trial within a reasonable time by an independent and impartial court in determining civil rights and responsibilities.

Currently, the judges of the first instance, who bear the main and heaviest burden of resolving civil disputes, organize and conduct claims against individuals and entities, ensure the conduct of the trial, control the and are responsible for the work of secretaries, etc., which they should not do in principle. This takes a long time for the judge to spend on cases.

Therefore, the release of judges from their noncharacteristic organizational and administrative functions will allow them to have a real opportunity to hear a large number of court cases in a timely manner.

There are differing views in the literature on civil procedural law about the relationship between the objectives and objectives of civil proceedings. In our opinion, the court's performance of the task of properly and in a timely manner to consider civil cases is a prerequisite for achieving the stated in Art. 150 GPC goals. These goals, the formation of respect for the law and the court can be achieved only as a result of the fair and professional performance of the courts set before them.

The objectives and objectives of civil proceedings defined in Art. 4 GPC RK, allow to correctly in- 
terpret the rules of civil procedural law on the basis of their actual meaning (Yurova 2008 c: 37).

The Court is a binding subject of any procedural legal relationship, and its power is limited by law and is balanced by the procedural capacity of those involved in the proceedings. Each such person, being the second party of civil procedure, has the right to require the court to perform its procedural duties and, accordingly, to perform certain actions. The court has a similar right (Erpylova 2015:23-26). A civil process is a legal relationship between a court and a disputed party, with its purpose or recognition by a court of civil law belonging to one party because of the denial of this right by the other party, or by non-recognition of that right in view of assertions of the opposing side of the existence of it in its face (Bahin 2003:13).

Therefore, the GPC should take into account the special nature of civil procedure in the formulation of the concept of "parties" in the civil process. Thus, procedural relations should be defined in the legislation as the most important real legal category and the most important guarantee of an adversarial, lawful and fair trial. Finally, we believe that compliance with the moral principles of society, the rules of business ethics inherent in material law, may have difficulties in implementing them in a procedural manner, for example in the process of proof, where the evaluation of evidence strictly formalized and does not, we believe, give wide opportunities to appeal to the rules of business ethics and fairness. Indication in Art. 16 GPC that the judge evaluates the evidence on his own internal conviction, based on an impartial, comprehensive and full examination of the evidence available in the case in their totality, guided by the law and conscience, is clearly insufficient, as it is. Contained in Art. The 68 GPC provisions were certainly more formalized than the ethical notion of "conscience", and the judge was more inclined to apply certain provisions of the law than to be guided by his conscience (Shak 2001:2-3).

An important problem with the procedural code remains the creation of a whole set of rules based on the original ideas, legal principles that permeate and cement the entire procedural mechanism. In general, the importance of judicial and judicial principles, and by their totality should be understood the fundamental tenets of the new branch of judicial law, cannot be overestimated. National constitutions and laws. It can be argued that the principles of material and procedural law are most directly involved in the regulation of legal relations, as are the rules of law itself. Principles define not only the "letter" but also the "spirit" and meaning of the law, which allows judges to wisely combine the most stringent imperatives with the beginnings of humanism and justice. Ultimately, the point of this requirement is that the civil process provided the right decisions of the courts (Neshatayeva 2004:366).

In our opinion, most of the comments on the structure, general logic, legislative technique, principles and many other issues regulated by the GPC are related to the absence of serious theoretical study on a number of basic provisions of the code procedural problems and, as a result, a formal approach to many procedural rules and institutions (Klein 2018:15).

As already indicated, the regulatory exercise of civil procedure rules is due in large part to the need to adequately implement the rules of material law in the event of a dispute or other problems that make it difficult to implement certain or other rights (protection of statutory interest). To what extent the procedural procedure reflects in its inherent form the specifics of the method of legal regulation of a particular branch of material law, to what extent this procedure takes into account the peculiarities of material law and whether there is a scientifically sound concept, allowing the means of legislative technology, stylistics and semantics to reflect in procedural form the preservation of principled ideas inherent in material law - these and a number of other issues, the authors of the code, it seems to us, did not pay attention to due attention (Mamaev 2008:53).

Examples include civil law rules that ensure the fair, reasonable and fair exercise of their rights by citizens and legal entities, adherence to the moral principles of society, business rules Ethics. Integrity, reasonableness and fairness of the actions of participants in civil legal relations are assumed (Article 8 of the GPC). However, these provisions are not fully incorporated into procedural legislation. Okay, in Art. 218 GPC notes that the court's decision should be lawful and justified. But there are many examples where a formally lawful and reasonable decision is unjust and not in accordance with the moral principles of society. However, the principle of fairness has not been adequately reflected in the GCC.

Private legal procedural form is necessary for resolving conflicts between materially equal subjects, which predetermines the possibility and necessity of maximum equality of the parties in adversarial and dispositive process. This form, in turn, taking into account the specifics of economic disputes involving professional economic entities, is divided into civil and arbitration proceedings. It cannot be excluded that other procedural forms may arise in the future, if it is required by consideration of newly 
formed groups of cases with specialized features (for example, bankruptcy cases, and labor cases). Thus, the external differentiation of the procedural form depends and is directly related to the types of proceedings used for realization of judicial activity. At present, G.L. Osokina, for example, substantiates the existence of arbitration proceedings as norms regulating the procedure of consideration and resolution of civil cases by arbitration courts, which represent a full element of the system of civil procedure law (Osokina 2008:69).

In addition to the external differentiation of the procedural form, there is also its internal division: in addition to the traditional types of civil and arbitration proceedings, such as claim, special, "simplified" procedural rules are used to consider cases not related to the resolution of the conflict, to establish the actual circumstances of the case, which have not all, but only the most essential features of the private legal procedural form, in which the basic principles of judicial activity are implemented. These forms create an opportunity not to burden the court and the participants in the process with a long and costly trial. At the same time, they will make it possible to ensure certain guarantees of legality in each specific case, which are necessary to give legal effect to a judicial act issued as a result of such proceedings, which is binding on all State authorities, local selfgovernment bodies, public associations, officials, citizens and organizations without exception and is subject to strict enforcement throughout the Russian Federation. At the same time, the latest procedural codes have shown a significant modernization and expansion of various simplified procedures, which is associated with the process of optimization of court proceedings and judicial activities, under which simple, indisputable cases were supposed to be considered without the use of extensive ordinary regulations. The simplification of the procedure arises when the process is conducted without summoning the parties, i.e. without a court session (Treushnikov 2002:7-18).

Law enforcement and law enforcement activities are characteristic of both jurisdictional and other bodies protecting citizens' rights by resolving legal and social conflicts. Law enforcement relations are the activities of bodies empowered by virtue of their specific competence to carry out activities related to the application of certain regulatory requirements. This activity is peculiar to both jurisdictional and all other bodies related to the application of normative acts (e.g. public organizations, economic, etc.).

Enforcement as an activity does not exist by itself. This activity has a general direction - the application of law and, presumably, special purposes.

The essence of justice is expressed in the fact that only the court may rule on cases under consideration in accordance with the procedure established by law; any annulment or amendment of a court decision is permissible only by a higher court and only in accordance with the procedure established by the procedural legislation, i.e. in the form of a court hearing. Justice has special features that make it possible to distance this type of state activity from its other types, which are concluded:

1) The administration of justice on behalf of the State;

2) The specificity of the means and methods justice is administered in the form of court sessions;

3) The administration of justice in the strictly procedural form established by procedural legislation;

4) In the administration of justice by special State bodies - the courts;

5) The wide publicity of judicial proceedings (Shvedova 1989:853-856).

Civil and procedural legal capacity is closely linked, but this is not an identical relationship. Procedural legal capacity in its objective aspects and in the subjects to which it belongs does not coincide with civil legal capacity. It has been established that civil rights can be protected not only through civil proceedings. A number of civil rights, for example in the area of housing, labor, land and other legal relations, are protected through administrative procedures. Conversely, it may be possible to demonstrate procedural legal capacity in disputes in the field of such legal relations, which are excluded from the scope of civil law activities of the person (Princekin 2015: 89).

\section{Литература}

Баймолдина 3.Х. Гражданское процессуальное право Республики Казахстан: Учебник. В двух томах. Т. І. Общая часть (темы 1-15). - Алматы: КазГЮА, 2001. - С. 44.

См., например: Рожкова М.А. Мировая сделка: использование в коммерческом обороте. - М.: Статут, 2005. - С. 12.

Юрова Н.М. Международное гражданское процессуальное право: теоретические основы имплементации норм в правовой системе Российской Федераций. - М.: Волтерс Клувер, 2008. - С. 14-15.

Подробнее изложение позиции авторов и ссыки на источники см.: Юрова Н.М. Указ. соч. 2008. С. 12-34. 
См.: Юрова Н.М. Указ. соч. 2008. С.37.

Актуальные проблемы гражданского процесса: Материалы конференции / Под ред. С.В. Бахина - СПб., 2003. - С. 13.

Шак Х. Международное гражданское процессуальное право: Учебник / Пер. с нем. - М.: Изд-во БЕК, 2001. - С. 2-3.

Нешатаева Т.Н. Международное частное право и Международный гражданский процесс: Учебный курс в трех частях. - М.: ОАО Изд. дом Городец, 2004. - С. 366.

Ерпылева Н.Ю. Международное частное право: Учебник для бакалавров и магистрантов. В 3 т. Том 3. - М.: Изд-во Юрайт, 2015. - С. 23-26.

Мамаев А.А. Международная судебная юрисдикция по трансграничным гражданским делам. - М., 2008. - С. 53.

Klein N.I. Settlement of disputes in the CIS countries, with business activity. 2018. p. 15.

Осокина Г.Л. О сущности производств по делам об оспаривании решений третейских судов и о выдаче исполнительных листов на принудительное исполнение решений третейских судов // Тенденции развития гражданского процессуального права России: Сб. науч. статей. - СПб., 2008. - С. 69.

Треушников М.К. Развитие гражданского процессуального права России // Заметки о современном гражданском и арбитражном процессуальном праве. - М., 2004. - С. 20; Громошина Н.А. Административное судопроизводство: точка зрения процессуалиста // Актуальные проблемы гражданского права, гражданского и арбитражного процесса. Ч. 2. Воронеж, 2002. - С. 7-18.

Ожегов С.И. Словарь русского языка: 70000 слов / Под ред. Н.Ю. Шведовой. - 21-е изд., перераб., и доп. - М.: Русс яз., 1989. - С. $853,856$.

Князькин С.И., Юрлов И.А. Гражданский, арбитражный и административный процесс в схемах с комментариями: учебник. - М.: Инфротропик Медиа, 2015. - С. 89.

\section{References}

Baımoldına Z.H. Grajdanskoe protsessýalnoe pravo Respýblıkı Kazahstan: Ýchebnık. V dvýh tomah. T. I. Oba1a chast (temy 1-15). Almaty: KazGIýA, 2001. S.44.

Sm., naprımer: Rojkova M.A. Mirova1a sdelka: ıspolzovanıe v kommercheskom oborote. M.: Statýt, 2005. S.12.

Iýrova N.M. Mejdýnarodnoe grajdanskoe protsessýalnoe pravo: teoretıcheskıe osnovy implementatsı1 norm v pravovo1 sisteme Rossi1sko1 Federats11. M.: Volters Klýver, 2008. S.14-15.

Podrobnee 1zlojenıe pozıts11 avtorov 1 ssyk1 na 1stochnık1 sm.: Iýrova N.M. Ýkaz. soch. 2008. S.12-34.

Sm.: Iýrova N.M. Ýkaz. soch. 2008. S.37.

Aktýalnye problemy grajdanskogo protsessa: Materıaly konferentsı / Pod red. S.V. Bahına SPb, 2003. S.13.

Shak H. Mejdýnarodnoe grajdanskoe protsessýalnoe pravo: Ýchebnık / Per. s nem. M.: Izd-vo BEK, 2001. S.2-3.

Neshataeva T.N. Mejdýnarodnoe chastnoe pravo 1 Mejdýnarodnyı grajdanskı1 protsess: Ýchebnyı kýrs v treh chastıah. M.: OAO Izd. dom Gorodets, 2004. S.366.

Erpyleva N.Iý. Mejdýnarodnoe chastnoe pravo: Ýchebnık dlıa bakalavrov 1 magıstrantov. V 3 t. Tom 3. M.: Izd-vo Iýrait, 2015. S.23-26.

Mamaev A.A. Mejdýnarodnaıa sýdebnaıa 1ýrısdıktsı1a po transgranıchnym grajdanskım delam. M., 2008. S.53.

Klein N.I. Settlement of disputes in the CIS countries, with business activity. 2018. P.15.

Osokına G.L. O sýnostı proızvodstv po delam ob osparıvanı1 reshenı1 treteıskıh sýdov 1 o vydache 1spolnıtelnyh listov na prinýdıtelnoe 1spolnenie reshenı treteıskıh sýdov // Tendents11 razvitıa grajdanskogo protsessýalnogo prava Ross11: Sb. naých. state1. - SPb, 2008. S.69.

Treýshnıkov M.K. Razvitıe grajdanskogo protsessýalnogo prava Rossı // Zametkı o sovremennom grajdanskom 1 arbitrajnom protsessýalnom prave. - M., 2004. S. 20; Gromoshına N.A. Admınıstratıvnoe sýdoproızvodstvo: tochka zrenı1a protsessýalista // Aktýalnye problemy grajdanskogo prava, grajdanskogo 1 arbitrajnogo protsessa. Ch. 2. — Voronej, 2002. S. 7 - 18.

Ojegov S.I. Slovar rýsskogo 1azyka: 70000 slov / Pod red. N.Iý. Shvedovo1. 21-e 1zd., pere rab, 1 dop. M.: Rýss 1az., 1989. S. 853,856

Knıazkın S.I., Iýrlov I.A. Grajdanskı1, arbıtrajnyı 1 admınıstratıvnyı protsess v shemah s kommentarıamı: ýchebnık. M.: Infrotropık Medıa, 2015. S.89. 